\title{
Interpretations of modernity and the problem of world-making*
}

\section{Peter Wagner}

ICREA and University of Barcelona

peter.wagner@ub.edu

Received: 22-07-2014

Accepted: 15-05-2015

\begin{abstract}
The term cosmopolitanism both expresses an attitude towards our present time and provides certain keys to analyse it. This article aims to better understand the revival of cosmopolitanism since the end of the twentieth century by confronting conceptual developments in the social and political theory of modernity with the historical experiences of interpreting and institutionalizing modernity. At the heart of the matter are views about the prevailing social bonds between human beings and their implication for building and maintaining political institutions. The common view of modernity as marked by trends towards individualization and instrumental rationalization is redefined as one interpretation of modernity among others; and the current situation is regarded as a struggle over world-interpretations rather the imposition of linear trends towards globalization and individualization, a view that was dominant at the same time as cosmopolitan thinking revived.
\end{abstract}

Keywords: cosmopolitanism; globalization; individualization; modernity; instrumental rationality

* Work on this article has benefitted from funding by the European Research Council for the Advanced Grant project "Trajectories of modernity: comparing non-European and European varieties" (TRAMOD, grant no. 249438) 
Resumen. Las interpretaciones de la modernidad y el problema de hacer mundo

El término cosmopolitismo expresa una actitud hacia nuestra época actual y, al mismo tiempo, proporciona ciertas claves para analizarla. Este artículo pretende comprender mejor el resurgimiento del cosmopolitismo desde finales del siglo xx mediante la confrontación de los desarrollos conceptuales de la teoría política y social de la modernidad con las experiencias históricas de interpretación e institucionalización de la modernidad. En el centro de la cuestión se hallan los puntos de vista sobre los vínculos sociales que prevalecen entre los seres humanos y las implicaciones que estos tienen para la construcción y el sostén de las instituciones políticas. La idea común de la modernidad marcada por las tendencias hacia la individualización y la racionalización instrumental se redefine como una interpretación de la modernidad entre otras, y se considera la situación actual más como una lucha en torno a las interpretaciones mundiales que como la imposición de tendencias lineales hacia la globalización y la individualización, la perspectiva dominante en el momento del resurgir del pensamiento cosmopolita.

Palabras clave: cosmopolitismo; globalizacion; individualizacion; modernidad; racionalidad instrumental

Summary
$\begin{array}{cl}\text { The social theory of modernity } & \text { Rethinking modernity } \\ \text { The political theory of modernity } & \text { The current condition of modernity } \\ \text { Social and political ontology } & \text { Bibliographic references }\end{array}$

The past two decades have witnessed a revival of the term cosmopolitanism in public and scholarly debate. Numerous of the early contributions made references to the bicentennial and hundred-and-fiftieth anniversary, respectively, of the publication of two landmark writings on this matter: in 1795, Immanuel Kant offered reflections on the way Towards perpetual peace; and in 1848, Karl Marx and Friedrich Engels published their Manifesto of the Communist Party. We can understand the former as a politico-philosophical analysis of the conditions for orderly international relations to emerge; and the latter as a socio-economic analysis of what now is being called globalization, namely the ever wider extension of social relations potentially across the whole globe.

Clearly, the revival of debate was not motivated by celebrating anniversaries in intellectual history. Rather, these time-honoured writings were dug out because they suddenly seemed to speak to the current situation. Among the recent changes that triggered the interest, the fall of Soviet socialism was particularly significant. It brought a bipolar global constellation to an end as well as the related habit of speaking about three contemporary worlds - the First World of liberal-democratic capitalism, the Second World of existing socialism, and the Third World of modernization and development. In turn, its demise was sometimes seen as due to the dynamics of global capitalism, in particular in the era of digital information and communication technologies, 
which the economic organization of Soviet socialism could not keep up with. In other words, the prevalent image was the one of an emerging singular world, united by globally extended socio-economic ties and requiring orderly relations between the existing states, which were de facto losing sovereignty due to increasing interdependence, but were not for that reason withering away (see Karagiannis and Wagner, 2007; Rosich, 2016 for detailed discussion). Let us call this, for reasons to be discussed later, an interpretation of modernity that emerged strongly from about 1990 onwards.

Kant's and Marx's reflections are certainly worth going back to. But what is often overlooked in re-reading them is the fact that their expectations about the future world, from their time of writing onwards, would turn out to be quite wrong. After Kant, the most devastating wars human history has seen were still to come. After Marx had written about the dissolution of all kinds of national bonds, nation-states were forming in Europe with ever tighter bonds between their citizens and erecting well-controlled boundaries towards the outside. Thus, rather than re-reading these authors to see whether their expectations might be closer to reality this time, a profoundly a-historical enterprise, it might be more useful to review the history of socio-political organization since their time of writing in the light of the assumptions about the relations between human beings and about the political forms in which they live together.

This, namely, is the underlying key question. Human beings entertain relations of various kinds and intensity towards each other: commercial, communicative, associative, affective, and others. Their analysis is the task of what we now call social theory, and guiding questions have been whether social life over time changes by strengthening some kinds of social bonds and weakening others, and what the consequences of any such trends are. And human beings also live in organized collectivities that share the rules that govern their lives in common. The analysis of these organizations and their rules is the task of what we now call political theory, and guiding questions have been to understand which forms of political organization are sustainable over time and which ones satisfy normative demands, such as importantly the commitment to freedom, both personal and collective. At the intersection of social and political theory, the question arises whether political organization requires a certain specificity and limited extension of social bonds. Cosmopolitan reasonings, in the broadest sense, tend to either deny that this is the case - all human beings can live well together - or suggest that our time has brought about a situation - of global extension of social bonds - in which these conditions of specificity and limitation no longer prevail.

In the following, I want to suggest that such conclusions follow easily neither from a conceptual nor from a historical review of socio-political changes since Kant's and Marx's times of writing. Following a widespread practice, I suggest we can analyse these two centuries with the help of the term "modernity" (and will explain later why). Thus, I will briefly and schematically first retrieve some key elements of the social theory of modernity and subsequently of the political theory of modernity with a view to showing both the different 
perspectives between them and the common underlying problématiques. To go beyond the divide, we need to adopt an ontology of social and political life that places language at its centre. Thus, we can recognize persistent variety in the interpretations of modernity and diagnose our present time as a struggle over world-interpretations in a particular context.

\section{The social theory of modernity}

The social theory of modernity emerged as a thinking about radical transformations in social relations during the long European nineteenth century, which is seen as lasting from 1789 to 1914 . Thus, we refer to a range of scholars reaching from Henri de Saint-Simon and G.W.F. Hegel to Alexis de Tocqueville and Karl Marx to Emile Durkheim, Max Weber and Georg Simmel. Across all differences between them, these authors had in common that they identified a profound rupture in social life that had brought about, or was to bring about, a radically new form of social relations and social structure. Even though they chose different terms for characterizing the rupture and the ensuing social transformation, and varied in the identification of the events that they saw as most significant for the transformation, they made the analysis of the emergent social formation their key concern, both because it was new and because it would mark the present and the future.

Modernity, in the sum of these authors' views, was characterized by a number of features that had been absent from the social world before the rupture or at least only of marginal importance. Modernity brought with itself a novel way of being-in-the-world and novel attitudes to the world as well as to other human beings, which were captured by terms such as abstract freedom, individual instrumental rationality, individualism, and occidental rationalism. The novel social constellation within which human beings find themselves and within which these attitudes grow, in turn, is captured by terms such as industry, division of labour, democracy, bourgeois society, working class, and capitalism. Even though earlier developments are sometimes mentioned, all these authors claimed that these attitudes and constellations emerged, or arose to dominance, in Europe from the late eighteenth and early nineteenth centuries onwards.

The emerging dominance of instrumental rationality weakens or destroys all other bonds between human beings. We can look at Marx and Engels's view as a particularly striking, strongly worded example. The Manifesto authors claim that the bourgeoisie "has pitilessly torn asunder the motley feudal ties that bound man to his 'natural superiors', and has left remaining no other nexus between man and man than naked self-interest, than callous "cash payment". It has drowned the most heavenly ecstasies of religious fervour, of chivalrous enthusiasm, of philistine sentimentalism, in the icy water of egotistical calculation." While the adjectives "feudal", "religious", "chivalrous" and also "philistine" refer to kinds of social bonds, Marx and Engels also thematize the predominant form of existence of those bonds that are bound to be destroyed, 
namely the national one. The bourgeoisie "has drawn from under the feet of industry the national ground on which it stood. All old-established national industries have been destroyed or are daily being destroyed. [...] In place of the old local and national seclusion and self-sufficiency, we have intercourse in every direction, universal inter-dependence of nations. And as in material, so also in intellectual production. The intellectual creations of individual nations become common property. National one-sidedness and narrow-mindedness become more and more impossible, and from the numerous national and local literatures, there arises a world literature."

While this overall perspective was developed up to 1920, roughly, it found a novel expression in post-Second World War social theory through Talcott Parsons's attempt at turning these observations on transformations of the social bond into a theory of "modern society". Appearances notwithstanding, Parsons, too, operated with the theorems of rationalization and individualization. He transforms the latter into a view of modern institutions as the institutionalization of freedom, and the former into seeing functional differentiation as the problem-adequate separate realization of different forms of rationality. Doubting the overall coherence of the framework, Parsons's critics returned to identifying trends of rationalization and individualization, aiming to assess tensions or harmonies between them as well as paradoxical normative consequences (see, for instance, Touraine, 1993; Honneth, 2004).

For further reflection, we retain that the social theory of modernity works with the notion of a forceful trend in the transformation of social bonds towards the hegemony of an individual-instrumental attitude to others. This can be called a "thin" bond (Walzer, 1994, for one use of the distinction "thick/thin" in political philosophy). At the same time, the form of existence of those bonds is of little interest. The focus is on trends rather than on institutions; and where institutions matter, such as in Parsons, they are all alike under conditions of modernity, because they are functionally determined.

This, at least, was the state of debate until recently. Over the past two or three decades, however, social theory has been thrown in disarray. One of the starting-points was the frontal attack by Jean-François Lyotard (1979), who suggested that the homogenizing conceptual language of social theory was inadequate for a social world that was marked by a plurality of language games. A little later, cultural phenomena were brought to central place by suggesting that, globally, there was no superior model of "modern society" but "multiple modernities" instead (Eisenstadt, 2000) and that, domestically, existing societies were becoming increasingly multi-cultural.

\section{The political theory of modernity}

The political theory of modernity had a very different intellectual trajectory. Witnessing the religious wars in Europe, it was concerned with establishing the possibilities for domestic peace. The preferred solution discussed during the seventeenth and eighteenth centuries was the social contract. Assuming human 
beings are first of all individuals, they had to get together and agree on ways of living together that would preserve both their lives and their liberty. The polity was seen as an association created by agreement - the contract - and for a purpose - safeguarding the life and liberty of its members. Variations notwithstanding, we can say that the reasoning was individualist and instrumentalist. It started out from human beings as individual atoms; and it postulated that their actions were rational towards a purpose.

Social-contract theory was one of the intellectual inspirations of the lateeighteenth century revolutions, and the constitutions written up after the revolutions to consolidate the new order were regarded as social contracts. But in the aftermath of the revolutions political thinking changed, not least because it had to take the new political reality into account. French revolutionaries had sometimes stipulated that everyone who adhered to the principles of the republic could become a citizen of the new polity. They were addressing in an expansionist way an undecidable openness with regard to the boundaries of the republican polity. But elsewhere one recognized the expansionism through the Napoleonic wars, which one could see as liberating from the Old Regime or as imperial or as a combination of both.

Intellectually prepared before the Revolution, by authors such as Johann Gottfried Herder, a connection between liberalism and nationalism arose outside of France. The central idea was that polities should be formed by speakers of the same language. We may call this the cultural-linguistic theory of the polity. It gave an answer to the question where the boundaries of a modern polity should be, namely defined by the linguistic community. As to why this should be so, the reasoning contains different nuances. One can take the cultural-linguistic theory as considering the abstract liberalism as too demanding: if people have nothing else in common, they will not be able to live together just by abiding to an instrumental agreement. They have to be known as sharing values, and common language is a good indicator for shared values, because language is world-constituting. But one can also read the approach more pragmatically: in the modern polity the citizens will have to communicate with each other about the matters they have in common and common measures they might need to take. Not everything will already be contained in the constitutive contract. And the precondition for communication is a common language. If individualist instrumentalism works with a thin view of the social bond, the cultural-linguistic theory works with a much thicker one.

The cultural-linguistic theory of the polity put its mark on the European nineteenth century. It inspired movements for national unification where speakers of the same language lived in different polities, such as German and Italian speakers; and it inspired movements for national liberation where speakers of one language co-existed with speakers of other languages in one polity and when one of those languages was dominant. This was the case for Greek speakers in the Ottoman Empire, for various language groups in the Austro-Hungarian Empire, and for Catalan and Basque speakers in Spain, among others. 
Between the late nineteenth century and the middle of the twentieth century, the mostly rather liberally oriented cultual-linguistic approach to polity formation turned increasingly dogmatic and aggressive in the course of the "nationalisation of European societies" (Noiriel, 1991), which we cannot analyse in detail here. Within these societies, the "national question" and the "social question" were considered to be the key challenges one had to address; and the hope was that the answer to one could be supported by the answer to the other. But after the First World War, the answers to the single questions were radicalized each on their own. With Nazism, the nation was turned into an existential collectivivity - just as class was in Stalinism (Heller, 1991).

After the end of the Second World War, European polities were rebuilt by limiting the range of permissible political discourse. The liberal-democratic welfare and nation-states that emerged within Western Europe can be seen as combining elements of national and social responses to the key nineteenthcentury questions with the liberal-democratic commitment. This compromise worked rather well in numerous cases, though not in all. But at its roots was an unacknowledged ambiguity between the underlying organizing principles, covered up by the moderately well functioning of the arrangement. The main form of political organization remained national-territorial, whereas liberaldemocratic and social components were introduced into those containers.

Thus, in political terms, Europe has been dominated by attempts to arrange socio-political life in rather closed, territorially circumscribed communities in which speakers of the same language would live together, while being separated from speakers of other languages with whom one would entertain only relations of low intensity and little significance. Such attempts have never been entirely coherent conceptually nor entirely successful institutionally. Nevertheless, the image of the world that was thus created has remained dominant until recently.

But until recently only: as our opening remarks indicated, the current debate on cosmopolitanism suggests that these socio-political containers are leaking on all sides, if they are not disintegrating entirely. Terms such as "the decline of the nation-state" capture descriptively the decreasing control by the state of phenomena, such as the economy or education, over which it used to have a considerable amount of control. Conceptually, furthermore, it points to the end of a model of political integration, by "thick", cultural-linguistic means namely.

\section{Social and political ontology}

Hopefully, these accounts of the history of social and of political theory over the past two centuries have been plausible - despite or because of their brief and schematic nature. Two features should have become visible: in historical perspective, on the one hand, there is almost complete asynchronicity between the two approaches. Before the onset of modernity, the world is characterized by a large variety of thick social bonds, "motley feudal ties", for social theory, 
whereas political theory develops the individualist-instrumentalist approach to polity constitution, in which "thinness" of social bonds is a precondition. In the course of the history of modernity, social theory diagnoses unstoppable processes of individualization and rationalization, tearing down all walls and fences, whereas political theory comes up with the cultural-linguistic theory of the polity, which justifies strong boundaries. At the current moment, finally, social theory rediscovers multiplicity and strength of social bonds, whereas political analysis observes the strain on institutions due to individualization and globalization.

In conceptual terms, on the other hand, the approaches overlap at some points, but they tend to answer similar questions by different means. Social theory observes and reflects on changes in social relations, and then may draw conclusions from its insights for political forms, their viability and/or their desirability. Political theory, in turn, observes and reflects on political forms, and then may ask whether these forms do not have requirements with regard to the nature and structure of social relations among its members. Such difference of perspective can be enriching, but the diversity of outcomes - both interpretation of history and conceptual reasoning - is troubling and in need of explanation. We cannot do so here for the whole intellectual history that we briefly sketched (elements can be found in Wagner, 2001; and Wagner, 2008: ch. 13). But we can make one observation on issues of social and political ontology that inform the dichotomous conceptualizations (in this section), to be followed by a reflection on ways of theorizing modernity that vary with the ontological position one takes (in the subsequent section).

Above, we have described a "thick" way of seeing language, namely as expressing a whole way of being. In this view, our language is indicative of, and a correlate to, our values, our culture, our morals, in short: to our self. This view is built on the insight that human beings are "self-interpreting animals" (Taylor, 1995, on which the following draws) and that language is constitutively social. Herder, as mentioned above, is a key reference for this view. But this is not the only way of seeing language. The "thin" alternative sees language as a means of instrumental communication with others. It is a tool to be applied for a purpose. "To make oneself understood", in this perspective does not signify "to convey who one is", but rather "to explain what one aims to obtain".

Two very different ways of regarding the task of translation emerge from this distinction. In the former understanding, a translator would aim at bringing out that which is specific to expressions in the particular language. In the latter understanding, the translator would identify the purpose of the statement and underline it. As an eminent social and political theorist once said to me in private communication, applying this latter view: "If something cannot be said in English, it is not worth saying at all."

To return briefly to the preceding discussion for illustration: The "container image" of the world had assumed that human social life could flourish because all significant relations could be both handled (instrumentally) and 
expressed (creatively, affectively, ...) through the dense web of significations provided by a common language. A world in which strong boundaries have disappeared, in turn, would need to operate with a "thin" universal language that most speakers learn as a second language and that would presumably be mostly used instrumentally and/or through translation across first languages that would shift the burden of conveying "thick" meaning onto the capacity for translation, whether by the actors themselves or by intermediaries.

It is not difficult to arrive at the conclusion that language is, obviously, both instrumental and expressive. But further questions follow. First of all, the two views of language do not simply co-exist; the former is contained in the latter. Expressing instrumentality is one way of expressing oneself. The instrumental use of language is thus a specific case among language's expressive possibilities.

In this light, secondly, the socio-theoretical interpretation of the history of European modernity signals a shift in the predominant ways of expressing oneself. From among a broader range of human possibilities, the instrumental one gains ever further dominance. This is a way of looking at social transformations as transformations in the relations between human beings as expressed in language use. Normatively, it can be regarded as an impoverishment or as an increase in functionality.

Therefore, thirdly, one can ask which use of language is adequate in which context. Rather than rejecting it throughout, advocates of the "thick" view of language will accept that instrumental use is adequate in some contexts. For our discussion, the question is whether an instrumental use of language is adequate among the members of a polity with a view to determining the rules for life in common. Clearly, polities are not associations that human beings create or join for a purpose. They are collectivities of human beings who already live with each other, in some broad sense, mostly understood as sharing a territory. But as social-contract theorists maintain, one might not rule out that looking at polities as if they were associations for a purpose could bring some benefit. To understand that benefit, if any, we need to explicitly explore for a moment the question of modernity.

\section{Rethinking modernity}

Modernity is best seen as an imaginary signification of society (drawing on Castoriadis, 1975), and in particular as one that is built around the notions of autonomy and mastery. Such an imaginary was most strongly and clearly expressent in Enlightenment philosophy, but components and versions of it can be found at other times and places in human history. Importantly, there is one particular way of reading Enlightenment philosophy that emphasizes the centrality of the knowing subject, most clearly expressed in Descartes's Discours de la méthode. This way lends itself to interpreting autonomy as individual autonomy and mastery as instrumental mastery. Furthermore, this view, if valid, would help us understand why individualization and rationalization 
are dominant social trends under conditions of modernity. And lastly, this view also suggests that a polity formed by instrumentally minded individuals would be the epitome of the modern polity.

Interestingly, this image of modernity has mostly been painted by strong advocates of the model, such as some rational choice theorists and liberal-individualist political philosophers, and by those who strongly criticize and reject it, such as some scholars from post-colonial studies. Historico-sociological studies of the periods and places to which the term "modernity" is usually attached rarely found it convincing.

This representation narrows the angle from which modernity is looked at in rather the same way in which the instrumental view of language limits the view on language. The individualist-instrumental interpretation of modernity is one interpretation. It is a possibility within a much larger range of options. The imaginary signification of modernity does not provide any model for socio-political organization; it opens a space of interpretations within which debate and struggle over the most adequate interpretation at a certain place and time can take place.

To add some more concreteness: the general commitment to autonomy leaves open the precise relation between individual and collective autonomy. As the articulation between liberty and democracy, this question has occupied much of political theory over the past three hundred years. But the search for a theoretical answer is futile, because any of them can be contested from within the same frame of reasoning. Rather, human beings will need to create the relation between freedom and democracy within their polity in the light of their own history and experiences (see now Rosich and Wagner, 2016). Similarly, the commitment to mastery opens up further questions. One can aim at mastering oneself, other human beings, or nature - three rather different issues to which no general maxim can be applied. Furthermore, mastery is not necessarily instrumental mastery; it can be engagement with something or someone other that is better described as a hermeneutical relation, as understanding.

In other words, the history of modernity cannot be written as the history of the increase of individual autonomy and of instrumental mastery, up to the end-point of completing the "project of modernity". Rather, the history of modernity should be written as the history of the struggle over the adequate interpretation of modernity at one's own moment in space and time and in the light of one's experiences (Wagner, 2008, for more detail).

\section{The current condition of modernity}

This brings us back to the beginning and our observations on current cosmopolitanism. What is the current moment of modernity? What are our experiences with modernity up to this moment? What is the struggle over the interpretation of modernity today about, if there is any struggle?

Full answers to these questions are not at hand, but it is useful to look at the current situation in the light of the "container image" of the world 
as a representation of the "organized modernity" (Wagner, 1994) that had been built over the twentieth century. Recent debates, that is, debates of the 1990s, the moment of cosmopolitanism but also the moment of neo-liberalism, reflect the experiences with organized modernity as a constraint. Briefly, an alternative image emerged with roughly the following contours: Drawing on the sociological theorem of globalization and individualization, in a first step, much political discourse suggested that there is (and: should be) little, or nothing, between the individual human being and the globe. Every social phenomenon that stands in-between tends to be considered as having freedomlimiting effects. Significantly, the notion of democracy, which presupposes a specific decision-making collectivity and thus appears to stand necessarily in an intermediate position between the individual and the globe, tends to be redefined. Rather than referring to a concrete, historically given collectivity, processes of self-determination are, on the one side, related to social movements without institutional reference, and on the other side, projected to the global level as the coming cosmopolitan democracy. We can characterize this conceptual tendency as the erasure of space (for more detail on this reasoning, see Wagner, 2015a).

In a second step, we can identify a similar tendency towards the erasure of time. The individual human beings in question are seen as free and equal, in particular as equally free. Thus, their life-histories and experiences are no longer seen as giving them a particular position in the world from which they speak and act. In politico-theoretical terms, this view was most strongly defended by John Rawls in his Theory of Justice (1971), which is widely considered as the most influential treatise in political theory of the last half century. Rawls suggested that we hypothesize an "original position" in which human beings meet to determine the rules for their life in common, and that they act under a "veil of ignorance", ignoring all specific features of themselves and the others beyond being participants in this deliberation (for a recent critique, among many, see Mills, 2011). Reviving the tradition of social-contract theory, Rawls concomitantly returned to seeing societies as associations of individuals for a common purpose, neglecting the fact that human beings do not originally associate but always already live together with determinate others in determinate space and time.

But now we have moved beyond that moment. The undesirability and unsustainability of the space- and time-erasing image has widely been recognized. In very general terms, therefore, the reconstitution of meaningful temporality and spatiality is the core of the current struggle over re-interpreting modernity. The current work at re-interpretation takes place in the context of some common experience, because the degree of interconnectedness on the globe is today higher than in earlier periods (see Osterhammel, 2008, for an extended argument on this issue). Broadly, this is the experience of the dismantling of existing institutions and commitments of organized modernity without clear and concise guidance for their rebuilding. More specifically, in the face of the experience of attempted erasure of temporal and spatial signi- 
ficance, the current re-interpretation encounters the need for a high degree of justification for any spatio-temporally specific collective commitments.

But, as in earlier periods, socio-political situations today also vary considerably between regions. Varieties of organized modernity could have very different features. In South Africa, for instance, the constitutive feature of apartheid was the exclusion and oppression of the majority of the population. The reconstitution of modernity, thus, emphasizes equal freedom and equal rights as well as the reduction of social inequality. In the formerly socialist countries, in contrast, oppression often entailed the homogenization and standardization of life perspectives under conditions of limited social inequality; the emphasis for reconstitution, thus, is often on individual autonomy. The majority of the population of the so-called developing countries benefitted little from the exploitation of the earth's resources that was driven by the early industrialized countries. Today, thus, those benefits are claimed, while the earlier instrumental mastery of nature has led to ecological risks that need to be urgently addressed. In all these cases, finally, a reinterpretation of modernity will need to address the impact in the present of injustice committed in the past - the specific injustice of the past in different world-regions (see the contributions to Wagner, 2015b).

An analysis of the current world situation in terms of a modernity that is subject to a variety of possible interpretations permits overcoming the dichotomy between the images of closed containers rich with meaning, on the one hand, and an unbounded world dominated by thin instrumentality, on the other. The adoption of such a view, in turn, requires focusing on the issues that are at stake in the translation from one interpretation of modernity to another, most significantly the capacity to collectively embark on processes of worldmaking rather than being overrun by an allegedly self-propelled globalization. Given both the broadly common background in the withering away of markers of time and space and the different experiences with historically constituted forms of modernity, the creation of a singular world - be it cosmopolitan or neo-liberal or both - should not be expected, but a variety of world-making projects that will be in communication with each other without losing their specificities.

\section{Bibliographic references}

Castoriadis, Cornelius (1975). L'institution imaginaire de la société. Paris: Seuil.

Eisenstadt, Shmuel N. (2000). "Multiple modernities". Daedalus, 129 (1), 1-29.

Heller, Agnes (1991). "The concept of the political revisited”. In: Held, David (ed.). Political Theory Today. Cambridge: Polity, 330-43.

Honneth, Axel (2004). "Organized self-realization: some paradoxes of individualization”. European Journal of Social Theory, 7 (4), 463-78.

<http://dx.doi.org/10.1177/1368431004046703>

Karagiannis, Nathalie and Wagner, Peter (eds.) (2007). Varieties of world-making: beyond globalization. Liverpool: Liverpool University Press.

Lyotard, Jean-François (1979). La condition postmoderne. Paris: Minuit. 
Mirls, Charles W. (October 2011). "Decolonizing Western political philosophy". Paper presented at the TRAMOD conference "Political modernity in the 21 st century", University of Barcelona.

NoIRIeL, Gérard (1991). La tyrannie du national. Paris: Calmann-Lévy.

Osterhammel, Jürgen (2008). Die Verwandlung der Welt. Munich: Beck.

Rawls, John (1971). A theory of justice. Cambridge, Mass: Belknap of Harvard University Press.

Rosich, Gerard (January 2016). "Autonomy in and between polities". In: Rosich, Gerard and WaGneR, Peter (eds.). The trouble with democracy: political modernity in the $21^{\text {st }}$ century. Edinburgh: Edinburgh University Press.

Rosich, Gerard, and Wagner Peter (eds.) (January 2016). The trouble with democracy: political modernity in the $21^{\text {st }}$ century. Edinburgh: Edinburgh University Press.

TaYlor, Charles (1995). Philosophical arguments. Cambridge, Mass.: Harvard University Press.

Touraine, Alain (1993). Critique de la modernité. Paris: Fayard. $<$ http://dx.doi.org/doi:10.1522/030296063>

WaGner, Peter (1994). A sociology of modernity. London: Routledge.

- (2001). A history and theory of modernity. London: Sage.

- (2008). Modernity as experience and interpretation. Cambridge: Polity.

- (2015a). "Interpreting the present: a research programme". Social Imaginaries, 1 (1).

Wagner, Peter (ed.) (2015b). African, American and European trajectories of modernity: past oppression, future justice? Edinburgh: Edinburgh University Press (Annual of European and Global Studies, vol. 2).

WaLzer, Michael (1994). Thick and thin. Moral arguments at home and abroad, Notre Dame, Ind.: University of Notre-Dame Press. 